Сазонець І. Л. "1; ORCID ID : 0000-0001-6521-7815], д.е.н., професор,

Джинджоян В. В. ${ }^{[2 ;}$ ORCID ID: 0000-0003-0296-4092], к.е.н., доцент

${ }^{1}$ Національний університет водного господарства та природокористування, м. Рівне ${ }^{2}$ Дніпровський гуманітарний університет, м. Дніпро

\title{
СОЦІАЛЬНИЙ ПОТЕНЦІАЛ ТА ПЕРСПЕКТИВИ ФУНКЦІОНУВАННЯ САНАТОРНО-КУРОРТНИХ ПІДПРИЕМСТВ
}

У статті виявлено соціальний потенціал та перспективи функціонування санаторно-курортних підприємств. Установлено, що демографічна ситуація в країні визначає значущість санаторно-курортної діяльності в збереженні і поліпшенні здоров'я, підвищенні якості життя і трудового потенціалу населення.

Доведено, що ступінь задоволення попиту на санаторно-оздоровчі послуги обумовлюється формуванням пропозиції на дані послуги і санаторно-курортний продукт, які залежать від наявних можливостей або потенціалу організацій регіонального санаторно-курортного комплексу.

Констатовано, що поняття «потенціал» в загальновизнаному сенсі відповідно до тлумачення сучасних енциклопедичних словників означає «джерела, можливості, засоби, запаси, які можуть бути використані для вирішення будь-якої задачі, досягнення певної мети, можливості окремої особи, суспільства, держави в певній галузі (наприклад економічний потенціал)».

Резюмовано, що оцінка економічного потенціалу повинна розглядатися як комплексна система дій, що забезпечує розробку взаємозалежних управлінських рішень, які не суперечать один, кожне з яких вносить свій внесок в результативність всієї системи управління регіональним санаторно-курортним комплексом.

Ключові слова: потенціал; перспективи; підприємства; санітарнокурортні підприємства; економічний потенціал.

Постановка проблеми. Демографічна ситуація в країні визначає значущість санаторно-курортної діяльності в збереженні і поліпшенні здоров'я, підвищенні якості життя і трудового потенціалу населення. Система організації відновлення і підтримки здоров'я населення має багатопрофільний характер і багато в чому зумовлюється економічним потенціалом регіонального санаторнокурортного комплексу. При цьому вирішальне значення має 
економічне обґрунтування можливостей підвищення економічного потенціалу регіонального санаторно-курортного комплексу на базі наявних рекреаційних ресурсів, розробка спеціальної методики оцінки економічного потенціалу підприємств комплексу та ефективності його використання, що дозволяє виявляти детермінанти і траєкторію розвитку.

Ступінь задоволення попиту на санаторно-оздоровчі послуги обумовлюється формуванням пропозиції на дані послуги і санаторнокурортний продукт, які залежать від наявних можливостей або потенціалу організацій регіонального санаторно-курортного комплексу.

Аналіз досліджень і публікацій дав змогу встановити, що сучасні дослідники С. Войтович, В.Гуменюк, Н. Коваленко, Л. Крамченко, С. Сардак та ін. звертають свої наукові розвідки до проблеми виявлення соціального потенціалу та перспектив функціонування санаторно-курортних підприємств. Н. Ведмідь дослідив санаторно-курортний комплекс як системний об'єкт наукового пізнання та розробив методологічні основи типізації суб'єктів санаторно-курортної діяльності. А. Мазаракі вивчав структурні параметри розвитку санаторно-курортних та оздоровчих підприємств. О.Карий констатував взаємозв'язок і вплив на розвиток територій, організацій та окремих осіб категорій «імідж», «бренд» та «репутація».

Невирішені раніше частини загальної проблеми. Водночас здійснений теоретичний аналіз наукової літератури засвідчив, що згадана проблема знаходить відображення у низці нормативноправових актів, зокрема: Закон України «Про курорти», Постанови Кабінету Міністрів України від 11.07.2001 № 805 «Про затвердження Загального положення про санаторно-курортний заклад», «Про Комплексну програму соціально-економічного розвитку Великої Ялти як курорту загальнодержавного значення», Наказ Міністерства охорони здоров'я України від 28 жовтня 2002 р. № 385 «Про затвердження переліків закладів охорони здоров'я, лікарських, провізорських посад та посад молодших спеціалістів 3 фармацевтичною освітою у закладах охорони здоров'я», Наказ Держкомстату від 14 грудня 2011 р. № 345 та ін. Разом з тим, розвивальний поступ санітарно-курортних підприємств потребує нових досліджень щодо визначення перспектив їх розвитку.

Постановка завдання. Метою статті постає аналіз соціального потенціалу та перспективи функціонування санаторно-курортних підприємств. Для цього в якості методичного інструментарію 
наукових i прикладних розробок використовуватиме методи прогнозування, структурно-функціонального та економічного аналізу, загальнонаукові та економіко-статистичні методи, а також системний і комплексний логічний підходи до вивчення стану та тенденцій розвитку регіонального санаторно-курортного комплексу.

Основні результати дослідження. Ключову роль у санаторно-курортному комплексі посідають суб'єкти господарювання, які продукують послуги, спрямовані на запобігання втратам рекреаційної складової людського капіталу.

Специфіку суб'єктів санаторно-курортної діяльності можна охарактеризувати такими маркерами:

1) зорієнтованість: націлені на забезпечення як лікування, так і відпочинку населення;

2) природа приналежності: належать і до медицини, і до туризму;

3) соціально-економічний ефект: і запобігання втратам людського капіталу, і поповнення бюджет України;

4) вплив на суміжні сфери: проявляється і у прямому ефекті (сприяють як розвитку підприємництва у сфері будівництва, фінансових послуг, продовольства тощо), і в індукованому ефекті (забезпечують доходи місцевим резидентам у формі заробітної плати, дивідендів, орендної плати тощо);

5) глобальна роль: сприяють як визнанню особливого значення України у світовому рекреаційному процесі, так і у культурно-історичному розвитку світового суспільства.

Результати аналізування нормативно-правових актів, представлені у табл. 1, свідчать про неоднозначність виокремлення типів суб'єктів надання санаторно-курортних послуг. Зокрема, Закон України «Про курорти» такими суб'єктами визначає санаторнокурортні заклади, що розташовані на територіях курортів. Така неоднозначність тлумачення терміну «санаторно-курортні підприємства» детермінує плюралізм поглядів дослідників щодо виявлення соціальних потенціалів функціонування цих підприємств.

Різноманітність підходів до системного розуміння економічного потенціалу регіонального санаторно-курортного комплексу пояснюється наявністю складних взаємозв'язків з іншими видами потенціалів - виробничим, ресурсним, трудовим, інноваційним та іншими, що характеризує його як складну економічну дефініцію. Констатовано, що поняття «потенціал» в загальновизнаному сенсі відповідно до тлумачення сучасних енциклопедичних словників означає «джерела, можливості, засоби, запаси, які можуть бути 
використані для вирішення будь-якої задачі, досягнення певної мети, можливості окремої особи, суспільства, держави в певній галузі (наприклад, економічний потенціал)».

Таблиця 1

Виокремлення суб'єктів продукування санаторно-курортних послуг у нормативно-правових актах України

\begin{tabular}{|c|c|c|}
\hline Назви суб'єктів & $\begin{array}{l}\text { Нормативно-правовий акт, } \\
\text { джерело }\end{array}$ & $\begin{array}{c}\text { Сутнісна характеристика / типи } \\
\text { суб'єктів }\end{array}$ \\
\hline \multirow[t]{3}{*}{$\begin{array}{c}\text { Санаторно- } \\
\text { курортні заклади }\end{array}$} & $\begin{array}{c}\text { Закон України «Про } \\
\text { курорти» (із змін., внес. } \\
\text { згідно із Законом № 3370-ІV } \\
\text { (3370-15) від } 19 \text { січ. } \\
2006 \text { р., ВВР, 2006, № 22, ст. } \\
184)\end{array}$ & $\begin{array}{c}\text { Заклади охорони здоров'я, що } \\
\text { розташовані на територіях } \\
\text { курортів і забезпечують надання } \\
\text { громадянам послуг лікувального, } \\
\text { профілактичного та } \\
\text { реабілітаційного характеру з } \\
\text { використанням природних } \\
\text { лікувальних ресурсів }\end{array}$ \\
\hline & $\begin{array}{c}\text { Постанова Кабінету Міністрів } \\
\text { України (від 11.07.2001 № } \\
805 \text { «ро затвердження } \\
\text { Загального положення про } \\
\text { санаторно-курортний } \\
\text { заклад») }\end{array}$ & $\begin{array}{c}\text { Заклади охорони здоров'я, що } \\
\text { забезпечують надання } \\
\text { громадянам послуг лікувального, } \\
\text { профілактичного та } \\
\text { реабілітаційного характеру з } \\
\text { використанням природних } \\
\text { лікувальних ресурсів курортів із } \\
\text { застосуванням методів } \\
\text { санаторно-курортного лікування }\end{array}$ \\
\hline & $\begin{array}{c}\text { Наказ Міністерства охорони } \\
\text { здоров'я України (Про } \\
\text { затвердження переліків } \\
\text { закладів охорони здоров'я, } \\
\text { лікарських, провізорських } \\
\text { посад та посад молодших } \\
\text { спеціалістів } 3 \\
\text { фармацевтичною освітою у } \\
\text { закладах охорони здоров'я } \\
\text { Наказ Міністерства охорони } \\
\text { здоров'я України від } 28 \\
\text { жовт. 2002 р. № 385) } \\
\end{array}$ & $\begin{array}{c}\text { Бальнеологічні лікарні, } \\
\text { грязелікарні (у т.ч. дитячі), } \\
\text { курортні поліклініки, дитячі } \\
\text { оздоровчі центри, міжнародні } \\
\text { дитячі медичні центри, санаторії } \\
\text { (у т.ч. дитячі, однопрофільні, } \\
\text { багатопрофільні, спеціалізовані), } \\
\text { санаторії для дітей з батьками, } \\
\text { санаторії-профілакторії }\end{array}$ \\
\hline $\begin{array}{c}\text { Курортно- } \\
\text { рекреаційні } \\
\text { заклади }\end{array}$ & $\begin{array}{c}\text { Постанова Кабінету Міністрів } \\
\text { України (Про Комплексну } \\
\text { програму соціально- } \\
\text { економічного розвитку } \\
\text { Великої Ялти як курорту } \\
\text { загальнодержавного } \\
\text { значення від } 18 \text { вересня } \\
2001 \text { р. № 1206) } \\
\end{array}$ & $\begin{array}{c}\text { Санаторії, пансіонати з } \\
\text { лікуванням, пансіонати, будинки } \\
\text { відпочинку, дитячі оздоровчі } \\
\text { табори, туристичні готелі, } \\
\text { кемпінги і турбази }\end{array}$ \\
\hline
\end{tabular}


продовження табл. 1

\begin{tabular}{|c|c|c|}
\hline $\begin{array}{l}\text { Спеціалізовані } \\
\text { засоби } \\
\text { розміщування }\end{array}$ & $\begin{array}{c}\text { Наказ Держкомстату } \\
\text { України (від } 14 \text { груд. } 2011 \text { р. } \\
\text { № 345) }\end{array}$ & $\begin{array}{c}\text { Санаторії, пансіонати з } \\
\text { лікуванням, дитячі заклади } \\
\text { оздоровлення цілорічної дії } \\
\text { (дитячі центри), санаторії- } \\
\text { профілакторії, бальнеологічні, } \\
\text { грязе-, бальнеогрязелікарні, } \\
\text { будинки/пансіонати/бази } \\
\text { відпочинку, оздоровчі заклади } \\
\text { 1- 2-денного перебування, інші } \\
\text { заклади відпочинку (крім турбаз)) }\end{array}$ \\
\hline & $\begin{array}{l}\text { ДСТУ 4268:2003 (Послуги } \\
\text { туристичні. Засоби } \\
\text { розміщування. Загальні } \\
\text { вимоги: Національний } \\
\text { стандарт України) } \\
\end{array}$ & $\begin{array}{c}\text { Лікувальні та оздоровчі заклади } \\
\text { (санаторії, будинки реабілітації, } \\
\text { оздоровчі ферми тощо) }\end{array}$ \\
\hline $\begin{array}{l}\text { Колективні } \\
\text { засоби } \\
\text { розміщення }\end{array}$ & $\begin{array}{c}\text { ДСТУ 4527:2006 (Послуги } \\
\text { туристичні. Засоби } \\
\text { розміщення. Терміни та } \\
\text { визначення: Національний } \\
\text { стандарт України) } \\
\end{array}$ & $\begin{array}{c}\text { Бази відпочинку, будинки } \\
\text { відпочинку, дитячі табори, } \\
\text { курортні готелі, пансіонати, } \\
\text { профілакторії, санаторії }\end{array}$ \\
\hline $\begin{array}{c}\text { Підприємства для } \\
\text { відпочинку та } \\
\text { оздоровлення }\end{array}$ & $\begin{array}{c}\text { Основи законодавства } \\
\text { України про охорону } \\
\text { здоров'я Закон України (зі } \\
\text { змін., внес. згідно із } \\
\text { Законами № } 5036-V I \text { (5036- } \\
\text { 17) від } 4 \text { лип. } 2012 \text { р.) }\end{array}$ & $\begin{array}{c}\text { Будинки відпочинку, пансіонати, } \\
\text { туристські бази, інші } \\
\text { підприємства, установи і } \\
\text { організації, діяльність яких } \\
\text { пов'язана з організацією } \\
\text { відпочинку населення }\end{array}$ \\
\hline
\end{tabular}

Нині завдання регіонального розвитку полягає у визначенні максимальних резервів збільшення регіонального економічного потенціалу шляхом комплексного використання всіх його складових компонентів, що дозволяє розглядати потенційні можливості розвитку в перспективі.

В сучасних умовах соціальної складової економічного потенціалу надається особливе значення в силу того, що економічний потенціал повинен об'єднувати всі складові відтворення регіональної економіки, оскільки його використання здійснюється за допомогою взаємодії всіх елементів регіонального відтворення, що лежать в основі функціонування господарського комплексу регіону.

3 огляду на це економічний потенціал регіонального санаторно-курортного комплексу покликаний виконувати роль соціальної складової економічного потенціалу господарського комплексу регіону, який володіє лікувальними рекреаційними ресурсами.

Ступінь використання економічного потенціалу санаторно- 
курортного комплексу регіону визначається розвитком соціальноекономічних процесів регіональної економіки, а також ендогенними кількісними і якісними змінами мотиваційної поведінки споживачів цих послуг. В силу цього ступінь використання економічного потенціалу може виступати функцією від кількісних і якісних параметрів економічної і соціальної політики регіону.

Аналіз складових економічного потенціалу регіонального санаторно-курортного комплексу, представлених в різних джерелах, показав, що у авторів немає одностайності про підходи і структурні елементи даної дефініції.

Розкриваючи зміст економічного потенціалу рекреаційної зони, автори звертають увагу на характерні властивості економічного потенціалу. Це здатність, можливість виробництва продукції і створення певних благ як виробничою, так і невиробничою сферами регіону. На основі цього автори роблять висновок, що економічний потенціал рекреаційної зони можна розглядати як сукупність послуг, спрямованих на відновлення життєдіяльності людини в певних природних і кліматичних умовах зони.

До елементів економічного потенціалу зазначені автори відносять рекреаційну індустрію, рекреаційну інфраструктуру, міжгалузеві і внутрішньогалузеві зв'язки, а також міжрегіональні відносини, які знаходяться під впливом сукупності матеріальнотехнічної та соціально-економічних факторів.

У такому вигляді структура економічного потенціалу наближена по структурному складу до рекреаційного комплексу регіону, оскільки між ними відсутні значні відмінності. Оцінка економічного потенціалу повинна розглядатися як комплексна система дій, що забезпечує розробку взаємозалежних управлінських рішень, які не суперечать одне одному, кожне з яких вносить свій внесок в результативність всієї системи управління регіональним санаторнокурортним комплексом. 3 метою оцінки соціального потенціалу санітарно-курортних підприємств доцільно застосовувати єдину систему показників (табл. 2).

Таблиця 2

Система показників аналізування діяльності санаторіїв

\begin{tabular}{|l|c|c|}
\hline \multirow{2}{*}{ Підсистеми показників } & Показники & $\begin{array}{c}\text { Од. } \\
\text { виміру }\end{array}$ \\
\hline \multirow{3}{*}{ 1. Інфраструктури } & Чисельність & од. \\
\cline { 2 - 3 } & Загальна площа & м. кв \\
\cline { 2 - 3 } 2. Трудового потенціалу & Кількість ліжок (місць) & од \\
\cline { 2 - 3 } & Кількість штатних працівників & осіб \\
\hline
\end{tabular}


продовження табл. 2

\begin{tabular}{|c|c|c|}
\hline & $\begin{array}{c}\text { Кількість середнього медичного } \\
\text { персоналу }\end{array}$ & осіб \\
\hline \multirow{4}{*}{$\begin{array}{l}\text { 3. Господарської } \\
\text { діяльності }\end{array}$} & Доходи від наданих послуг & тис. грн \\
\hline & Обслуговано приїжджих & осіб \\
\hline & Використання місткості & $\%$ \\
\hline & Кількість проведених ліжко-днів & од. \\
\hline \multirow[t]{2}{*}{ 4. Соціальної ролі } & $\begin{array}{c}\text { Обслуговано постраждалих в } \\
\text { наслідок аварії на ЧАЕС }\end{array}$ & осіб \\
\hline & Обслуговано дітей & осіб \\
\hline \multirow{2}{*}{$\begin{array}{l}\text { 5. Зовнішньоекономічної } \\
\text { ролі }\end{array}$} & Обслуговано іноземців & ociб \\
\hline & $\begin{array}{c}\text { Фактично проведені ліжко-дні } \\
\text { іноземцями }\end{array}$ & од. \\
\hline
\end{tabular}

Висновки. Оцінка величини економічного потенціалу в абсолютному вираженні не може бути важлива сама по собі, а повинна бути використана як вихідна база для розрахунку рівня його використання, щоб виявити нереалізовані резерви підвищення економічного потенціалу. При проведенні оцінки економічного потенціалу слід використовувати середні величини, значення яких полягають в узагальненні сукупності однорідних показників і процесів, що дозволяє абстрагуватися від випадковості окремих значень оціночних показників. На практиці оцінка соціальноекономічного потенціалу i його складових 3 урахуванням їх кількісних і якісних характеристик $€$ досить проблематичною, i рішення цієї проблеми може перебувати в проведенні паралельної оцінки абсолютних і відносних величин, кількісних і якісних показників, що відіб'ється на отриманні більш об'єктивного результату.

Безумовно, слід вводити також порівняльну характеристику оцінки отриманого рівня використання економічного потенціалу регіону з аналогічною оцінкою рівня використання економічного потенціалу інших регіонів. Перспективи подальших розвідок у цьому напрямі вбачаємо у дослідженні особливостей синтезу соціального та комунікативного в реалізації програм освітнього туризму та визначення їх конкурентних переваг.

1. ВедмідьН. Санаторно-курортний комплекс як системний об'єкт наукового пізнання. Зб. наук. пр. Черкаського державного технологічного ун-ту. Сер. Економічні науки. 2014. Вип. 36(1.2). С. 43-51. 2. Ведмідь Н. Методологічні основи типізації суб'єктів санаторно-курортної діяльності. Вісник КНТЕУ. 2012. № 6. С. 72-83. 3. Войтович С.Я. Особливості дослідження та прояву поведінки споживачів санаторно-курортних послуг. Торгівля, комерція, підприємництво. 2014. Вип. 17. С. 75-78. 4. Гуменюк В. В. Тенденції податкового регулювання ринку санаторнокурортних послуг в Україні. Економіка розвитку. 2014. № 3. С. 18-24. 
5. Крамченко Л.І. Статистика ринку товарів і послуг: навч. посіб. 2-ге вид., виправл. та доп. Львів: Новий Світ-2000, 2007. 296 с. 6. Коваленко Н. Прогнозування розвитку санаторно-курортної діяльності в Україні. Схід. 2015. № 8. С. 25-29. 7. Мазаракі А. А., Ведмідь Н.І. Санаторно-курортні та оздоровчі підприємства: структурні параметри розвитку. Економіка розвитку. 2013. № 3. С. 51-55. 8. СазонецьІ.Л. Оціночні параметри якості рекреаційної діяльності санаторно-курортних підприємств. Інвестиції: практика та досвід. 2017. № 7. С. 1518. 9. Сардак С. Е., Джинджоян В. В. Маркетинг: навч. посіб. Дніпро: ДГУ, 2018. 242 с. 10. Сардак С. Е., Джинджоян В.В. Науково-методичні основи управління розвитком виробництва у національній економіці : монографія. Д. : Видавництво «Інновація», 2010. 175 с.

\title{
REFERENCES:
}

1. Vedmid N. Sanatorno-kurortnyi kompleks yak systemnyi obiekt naukovoho piznannia. Zb. nauk. pr. Cherkaskoho derzhavnoho tekhnolohichnoho un-tu. Ser. Ekonomichni nauky. 2014. Vyp. 36(1.2). S. 43-51. 2. Vedmid N. Metodolohichni osnovy typizatsii subiektiv sanatorno-kurortnoi diialnosti. Visnyk KNTEU. 2012. № 6. S. 72-83. 3. Voitovych S. Ya. Osoblyvosti doslidzhennia ta proiavu povedinky spozhyvachiv sanatorno-kurortnykh posluh. Torhivlia, komertsiia, pidpryiemnytstvo. 2014. Vyp. 17. S. 75-78. 4. Humeniuk V. V. Tendentsii podatkovoho rehuliuvannia rynku sanatornokurortnykh posluh v Ukraini. Ekonomika rozvytku. 2014 . № 3. S. 18-24. 5. Kramchenko L. I. Statystyka rynku tovariv i posluh : navch. posib. 2-he vyd., vypravl. ta dop. Lviv: Novyi Svit-2000, 2007. 296 s. 6. Kovalenko N. Prohnozuvannia rozvytku sanatorno-kurortnoi diialnosti v Ukraini. Skhid. 2015. № 8. S. 25-29. 7. Mazaraki A. A., Vedmid N. I. Sanatorno-kurortni ta ozdorovchi pidpryiemstva: strukturni parametry rozvytku. Ekonomika rozvytku. 2013. №3. S.51-55. 8. Sazonets I. L. Otsinochni parametry yakosti rekreatsiinoi diialnosti sanatorno-kurortnykh pidpryiemstv. Investytsii: praktyka ta dosvid. 2017. № 7. S. 15-18. 9. Sardak S. E., Dzhyndzhoian V. V. Marketynh: navch. posib. Dnipro: DHU, 2018. 242 s. 10. Sardak S. E., Dzhyndzhoian V. V. Naukovo-metodychni osnovy upravlinnia rozvytkom vyrobnytstva u natsionalnii ekonomitsi : monohrafiia. D. : Vydavnytstvo «Innovatsiia», 2010. 175 s.

\section{Sazonets I. L. ${ }^{[1 ;}$ ORCID ID: 0000-0001-6521-7815], Doctor of Economics, Professor Dzhyndzhoian V. V. [2; ORCID ID: 0000-0003-0296-4092], Candidate of Economics (Ph.D.), Associate Professor}

${ }^{1}$ National University of Water and Environmental Engineering, Rivne

${ }^{2}$ Dnipro University of the Humanities

\section{SOCIAL POTENTIAL AND PERSPECTIVES OF FUNCTIONING OF HEALTH RESORT ENTERPRISES}

\author{
The article reveals the social potential and prospects of functioning of \\ health resort institutions. It has been established that the demographic
}


situation in the country determines the importance of health resort functioning in maintaining and improving health, increasing the quality of life and the labor potential of the population.

The degree of demand satisfaction for health resort services is conditioned by forming the supply of these services and the health resort product, which in turn depend on the available capacity or potential of the regional health resort complex organizations.

It is stated that the concept of «potential» in the generally recognized sense, according to the interpretation of modern encyclopedic dictionaries means «sources, opportunities, means, reserves that can be used to solve any task, achieve a specific goal, the ability of an individual, society, state in a certain domain (such as economic potential)».

It is resumed that the assessment of economic potential should be considered as a complex system of actions that provides the development of interdependent management decisions that do not contradict one another and contribute to the effectiveness of the entire management system of the regional health resort complex.

Keywords: potential; prospects; enterprises; health resort enterprises; economic potential.

Сазонец И. Л. [1; ORCID ID: 0000-0001-6521-7815], д.э.н., профессор

Джинджоян В. В. [2; ORCID ID: 0000-0003-0296-4092], к.э.н., доцент

${ }^{1}$ Национальный университет водного хозяйства и природопользования, г. Ровно ${ }^{2}$ Днепровский гуманитарный университет, г. Днепр

\section{СОЦИАЛЬНЫЙ ПОТЕНЦИАЛ И ПЕРСПЕКТИВЫ ФУНКЦИОНИРОВАНИЯ САНАТОРНО-КУРОРТНЫХ ПРЕДПРИЯТИЙ}

В статье выявлены социальный потенциал и перспективы функционирования санаторно-курортных предприятий. Установлено, что демографическая ситуация в стране определяет значимость санаторнокурортной деятельности В сохранении и улучшении здоровья, повышении качества жизни и трудового потенциала населения.

Доказано, что степень удовлетворения спроса на санаторнооздоровительные услуги обуславливается формированием предложения на данные услуги и санаторно-курортный продукт, которые в свою очередь зависят от имеющихся возможностей или потенциала организаций регионального санаторно-курортного комплекса.

Констатировано, что понятие «потенциал» В общепризнанном смысле согласно толкованию современных энциклопедических словарей означает «источники, возможности, средства, запасы, которые могут 
быть использованы для решения любой задачи, достижения определенной цели, возможности отдельного лица, общества, государства В определенной отрасли (например, экономический потенциал)».

Резюмировано, что оценка экономического потенциала должна рассматриваться как комплексная система действий, обеспечивающая разработку взаимозависимых управленческих решений, которые не противоречат друг, каждое из которых вносит свой вклад в результативность всей системы управления региональным санаторнокурортным комплексом.

Ключевые слова: потенциал; перспективы; предприятия; санитарнокурортные предприятия; экономический потенциал.

Стаття надійшла до редакції 10.04.2020 р. 